\title{
Domestication, diversity and use of Brassica oleracea L., based on ancient Greek and Latin texts
}

\author{
Lorenzo Maggioni $(\mathbb{D} \cdot$ Roland von Bothmer • Gert Poulsen · Elinor Lipman
}

Received: 18 October 2016/Accepted: 11 April 2017/Published online: 28 April 2017

(C) The Author(s) 2017. This article is an open access publication

\begin{abstract}
The domestication process of Brassica oleracea L. has not been fully clarified, either regarding its initial location or the progenitor species involved. Two alternative hypotheses proposed so far point to either a northwest European or a Mediterranean location. Previous studies to clarify the domestication process focused on linguistic aspects and on the earliest occurrences in ancient literature of words referring to B. oleracea. Those studies are here extended to offer a comprehensive account of literary occurrences of the brassica vegetables in ancient Greek and Latin texts, between the VI century B.C.E. and the IV century C.E. This study offers a contribution to ancient ethnobotanical knowledge in the Mediterranean, including agricultural practices and culinary and medicinal uses. It also defines the time when increasing diversity of crop varieties is documented and it adds weight to the hypothesis of a Mediterranean location of the domestication of $B$. oleracea.
\end{abstract}

L. Maggioni $(\varangle) \cdot$ R. von Bothmer

Swedish University of Agricultural Sciences, Alnarp,

Sweden

e-mail: 1.maggioni@cgiar.org

L. Maggioni · E. Lipman

Bioversity International, Rome, Italy

G. Poulsen

University of Copenhagen, Copenhagen, Denmark
Keywords Brassica oleracea $\cdot$ Domestication · Culinary uses · Medicinal uses · Genetic diversity

\section{Introduction}

Cultivated varieties of Brassica oleracea L., often referred to as 'brassica vegetables' or 'cole crops' (Haynes et al. 2009) share a common C-genome made of nine chromosomes and are characterized by an outstanding diversification of morphological types. These must have differentiated under human selection, starting from a simple leafy type (leafy kale, var. viridis L.) into various highly valued modifications involving arrested development and enlargement of the inflorescences in broccoli (var. italica L.) and cauliflower (var. botrytis L.), folding of the leaves into 'heads' in cabbage (var. capitata L.), enlargement of the basal stem in kohlrabi (var. gongylodes L.), thickened stems in marrow-stem kale (var. medullosa Thell.), proliferation of heading buds in Brussels sprouts (var. gemmifera (DC.) Zenker), etc. A number of wild forms mainly growing on steep cliffs overhanging the Mediterranean Sea (more than ten species, with several endemisms) or the European West Atlantic coasts (B. oleracea L. subsp. oleracea) also share the $n=9$ C-genome and can be grouped together with the domesticated forms into a homogeneous interfertile group variously called ' $B$. oleracea group or cytodeme' or 'Brassica Section Brassica' 
(Snogerup et al. 1990; Gladis and Hammer 2003; Brullo et al. 2013).

The domestication process leading to the cultivated forms of B. oleracea L. has not been fully clarified, regarding either its initial location or the progenitor species involved (Zohary et al. 2012). Based on their ability to intercross with cole crops, all the $n=9$ C-genome wild Brassica species have been considered candidate wild progenitors. Before 1990, i.e. before the first relevant results of molecular genetics, a polyphyletic view prevailed about the domestication of the cole crops, with $B$. oleracea subsp. oleracea considered one of the ancestors, while other Mediterranean species had likely been involved in the origin of some of the cole crops (Thompson 1976; Snogerup 1980). Based on an analysis of nuclear restriction fragment length polymorphisms (RFLP), Song et al. (1990) concluded that wild B. oleracea subsp. oleracea seemed to be the closest to cultivated forms and, thus, most closely related to the ancestors of all cultivated B. oleracea, while other wild Brassica species with a Mediterranean distribution were more distantly related. As this taxon (B. oleracea subsp. oleracea) is only found on West European Atlantic cliffs in Britain, France, northern Spain and the German Islands of Helgoland and Rügen (and formerly also in Ireland) (Snogerup et al. 1990; Drenckhahn 2017), it has been hypothesized that the initial domestication took place on the Atlantic coast and early cultivated forms were brought from there to the Mediterranean, where selection for many of the early crop types occurred (Hodgkin 1995). More recently, Maggioni et al. (2010) proposed that a Mediterranean domestication would be supported by linguistic and literary considerations, since both Greek and Latin literature, from their earliest traces, are rich in expressions indicating a deep-rooted knowledge and use of the $B$. oleracea crops. Conversely, no accounts have been found of B. oleracea in any other early historical documents, from the Fertile Crescent, ancient Egyptian or Celtic civilizations.

Several authors have looked for literary or iconographic accounts of $B$. oleracea before, with the purpose of getting closer to understanding the origin of the related crops, their diversity and uses in the past (Helm 1960, 1963; Toxopeus 1974; De Saint-Denis 1980; Hodgkin 1995; Körber-Grohne 1995; Hondelmann 2002; Hervé 2003; Cerchiai Manodori Sagredo 2004; André 2009; Prakash et al. 2011; Toscano et al.
2013). The previous work of Maggioni et al. (2010) mainly concentrated on etymology and the search for the earliest accounts of B. oleracea in literature. This paper offers a more systematic survey of ancient Greek and Latin literature, aiming to give a more comprehensive, if not exhaustive, account of the references made to $B$. oleracea, ranging from the earliest Greek fragments of the VI century B.C.E., up to Latin texts of the IV century C.E. The existing forms of the cole crops during the period surveyed, the agricultural practices and the corresponding culinary and medicinal uses are described. Apart from offering a contribution to ethnobotanical knowledge related to the ancient Greek and Latin world, this study adds weight to the hypothesis of a Mediterranean location for domestication of B. oleracea.

\section{Methodology}

We used the general term 'cole' to refer to any $B$. oleracea crop, in order to avoid the ambiguity of words like 'cabbage' or 'kale' that are sometimes used in general terms, but can also be referred to specific crops of the $B$. oleracea group.

We derived a list of ancient Greek and Latin words that could be referred to B. oleracea from the Greek and Latin Lexica and Thesauri and other reference books and online services: Estienne ${ }^{1}$ (1831-1865); Facciolati et al. (1864-1887); Thesaurus Linguae Latinae (1906-1912); Ernout and Meillet (1932); Liddell and Scott (1982); André (2009); Thesaurus Linguae Graecae ${ }^{\circledR}$ (2014). Thesauri are reference books including all the forms of the words used and their location in ancient texts. These books were used to track down the occurrence of sentences referring to coles within the entire corpus of ancient Greek and Latin literature. Whenever possible, we then looked for the actual original texts and their translations into English, French or Italian. Useful online sites providing original texts or translations were the Perseus Digital Library, the Theoi Classical E-Texts Library, Bill Thayer's website, Corpus Scriptorum Latinorum

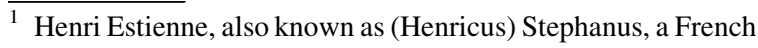
scholar and printer of the 16th century, produced the Thesaurus Graecae Linguae in 1572. This refers to the later (edited) printed version.
} 
and The Latin Library. For papyrological documents, we consulted the following online sources: the Hibeh papyri, Papyri info and POxy: Oxyrhynchus Online. As in some cases the available English translations were very old and did not use modern language, we have re-interpreted or re-worded some expressions, based on comparison with translations into other languages. Occasionally, we have directly translated the Greek or Latin texts.

The Greek words that we looked up as likely references to B. oleracea were krambē and rhaphanos. The Latin words were: brassica, caulis or colis and crambe (coles); cauliculos or coliculos (young stalks or small, tender shoots); cima or cyma (tender inflorescence tops); and (h)olus (generic green vegetables and specifically coles as of the I century C.E.). We were aware, based on the study made by Maggioni et al. (2010), that in some cases the same word had different meanings, depending on the Greek dialect (e.g. rhaphanos was used to mean 'cole' in Athens, but it meant 'radish' in other parts of Greece). In other cases, the same word changed its meaning with the passing of time, for example the meaning of caulis was initially simply the 'stem', but it started to mean the entire cole plant as of the I century B.C.E. Similarly, the word cauliculos may generically indicate tender shoots of any plant, but it refers specifically to $B$. oleracea if not otherwise specified. The word (h)olus initially simply had the meaning of 'vegetable', but subsequently, also around the I century B.C.E., it started to be used to specifically indicate the cole. These linguistic ambiguities remain a challenge, since the actual meaning of a word cannot always be derived from the literary context.

The collection of literary references related to the cole reported in the following sections of this paper is not an exhaustive list, but a wide selection of existing quotations for the period under study. We have not reported authors who did not seem to add new and original information or in case we were not able to track down original texts.

All the Greek words reported in this paper have been transliterated into English according to the romanization scheme laid out by the American Library Association and Library of Congress (Library of Congress 2010).

Brief notes on the biographies of ancient authors were taken from Wikipedia (www.wikipedia.org).

The following abbreviations were used:
- Agr. = De Agricultura [On Agriculture] by $\mathrm{CATO}^{2}$

- Deip. = Deipnosophistēs [the Deipnosophists] by Athenaeus

- Med. = De Medicina [On Medicine] by Celsus

- $N H=$ Naturalis Historia [Natural History] by Pliny (THE Elder)

- Op. agr. = Opus agriculturae [Treatise on farming] by Palladius

- $\quad P P H=$ Peri phyton historia [Enquiry into plants] by Theophrastus

- $\quad P Y I=$ Peri yless iatrikēs, also known as De Materia Medica [On medical matters] by DIOSCORIDES

- $R R=$ De Re Rustica [On Agriculture] by ColUMELLA / and also (same title) by VARro.

\section{Results}

Ancient Greek literature

Homer and Hesiod were the earliest authors of Greek literature to have reached us and their works are estimated to have been written in the VIII century B.C.E. Although the Homeric poems contain about 50 botanical names, coles are not mentioned (Forster 1936). The next oldest available works are fragments of comedy poems of the VI and V centuries B.C.E. In the comedies written by Ananius, Epicharmus, Eupolis and Teleclides (AthenAeus, Deip. 9.9), ${ }^{3}$ the word krambe is used to avoid sacred names as part of a comic oath. The expression Nai ma tēn krambēn can be translated as 'By the krambē!' and was used similarly to the current British 'By Jove!'. In a comedy by Hipponax of Ephesus, also from the VI century B.C.E., a 'seven-leaved $k r a m b \vec{e}$ ' is invoked as a magic or prophetic vegetable (Deip. 9.9). During the V and IV centuries B.C.E., Athenian poets Crates, Antiphanes, Nichocares and Alcaeus used the word rhaphanos in their comedies, speaking of a food that needs to be boiled (Deip. 1.62; 3.89; 9.10). Ephippus (IV century B.C.E.) listed boiled rhaphanos among the foods offered to new mothers during the Amphidromia family festival, which was celebrated on

\footnotetext{
$\overline{2}$ This format is used for the names of classical authors as listed in section 1 of the References (primary sources).

3 Translations from AthenAEus based on Canfora (2001).
} 
the fifth or seventh day after a mother gave birth (Deip. 9.10).

According to a fragment from Aplēstos [The Insatiable] by Diphilus Comicus (IV century B.C.E.), rhaphanos dipped in fat could be part of a rich meal (Deip. 9.10). Diphilus of Siphnos, physician of the III century B.C.E. informed us that a very good and sweet krambe grew in Kyme $\bar{e}^{-4}$ (Deip. 9.9), but beet was tastier and more nutritious than krambe (Deip. 9.11) and that shoots sprouting from krambe were used and called órmenos by the Attic people (Deip. 2.62).

Rhaphanos is present in the works of ARISTOPHANES (V-IV centuries B.C.E.), where it is tasted together with bread and oil and a sip of new wine ([Fragment] 109). ${ }^{5}$

The Batrachomyomachia [The battle of frogs and mice] is the title of a small poem, parody of the Iliad, wrongly attributed to Homer and possibly written by a certain Pigres of Halicarnassus. ${ }^{6}$ The date of writing is also uncertain, ranging between the $\mathrm{V}$ and I centuries B.C.E. In this poem the frogs prepare shields out of $k r a m b \bar{e}$ leaves and the names of two imaginary characters are Krambobatēs [Cole-climber] and Krambophagos [Cole-eater].

The use of rhaphanos or krambe as a preventive antidote before drinking or as remedy against drunkenness and its related headache is attested by writers of the IV and III centuries B.C.E.: Alexis, Amphis, Anaxandrides, Eubulus, Nichocares and Timaeus (in Athenaeus, Deip. 1.62), Theophrastus ( $P P H$ 4.16.6) and later in DiOsCORIDES (PYI 2.146-147).

The use for medicinal purposes is reflected by mention of a decoction of krambe (krambion) in HiPPOCRATES (V-IV centuries B.C.E.) (Gynaikeia $=$ De mulierum affectibus) [Diseases of Women] 1.63; 2.121).

Aristotle (IV century B.C.E.) in his Historia Animalium [History of Animals] (5.19.15), while mentioning that caterpillars chiefly grow on leaves of rhaphanos before becoming butterflies, also clarifies that rhaphanos and krambe are synonyms. ${ }^{7}$ In his

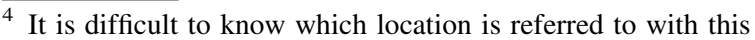
name, since different towns had a similar name, such as Cuma in today's Italy, Cyme in today's Turkey or Kymi in the Greek island of Euboea.

5 Translation from ARIsTOPHANES based on Henderson (2008).

${ }^{6}$ http://en.wikipedia.org/wiki/Pigres_of_Halicarnassus.

7 Translation from ARISTOTLE's Historia Animalium by Peck (1952).
}

Problemata [Problems] (3.17) he deals with the question why does krambe prevent headache after drinking. The answer is related to the properties of its sweet and purgative sap. In fact, the juice of krambe, drawn off after boiling and then cooled off, is used by physicians against diarrhea. In the case of those who are suffering from headache after drinking, the juice descends into the stomach and "draws off the moisture, which is vinous and unconcocted, and remaining itself in the upper abdomen it cools the body". ${ }^{8}$

A description of three types of rhaphanos can be found in THEOPHRASTUS (IV century B.C.E.), disciple of ARISTOTLE and botanist, who listed the curly-leaved, the smooth-leaved and the wild form (PPH 7.7.4). ${ }^{9}$

TheOphrastus also dedicated a chapter to uncultivated herbs:

Some of [the wild kinds] have the same names as the cultivated kinds; for all these kinds exist also in a wild form, and most of them resemble the cultivated kinds in appearance, except that in the wild forms the leaves and also the stalks are smaller and rougher, and in particular these forms are more pungent and stronger in taste, for instance, savory, marjoram, rhaphanos and rue... A peculiarity of 'wild rhaphanos' as compared with the others is that its stems are rounder and smoother than in the cultivated kind, and, while in the latter the attachment of the leaf is flat, in the wild kind it is rounder, and the leaf itself has fewer angles; in other cases the wild form is the rougher both in stem and leaf.

\section{—TheOPHRASTUS, $P P H$ 7.6.1-2}

The author had a certain notion of domestication, and he left us possibly with the earliest available description of this concept:

Thus the distinction between wild and cultivated seems to be due simply to cultivation, since, as Hippon ${ }^{10}$ remarks, any plant may be either wild or cultivated according as it receives or does not receive attention.

—TheOPHRASTUS, PPH 1.3 .5

\footnotetext{
$\overline{8}$ Translation from ARISTOTLE's Problemata based on Hett (1961).

9 Translations from Theophrastus based on Hort (1916).

${ }^{10}$ Ionian or Pythagorean philosopher of the V Century B.C., of which only few lines remain.
} 
THEOPHRASTUS offers also other details about rhaphanos and its cultivation. Plants such as rhaphanos and rue are given by THEOPHRASTUS as examples to indicate how difficult it is to establish clear-cut classifications, since they have only one stem as if they were trees, wherefore some call these 'tree-herbs' ( $P P H$ 1.3.4) and they can be classified as under-shrubs, due to their woodiness (PPH 6.1.2). Rhaphanos is also defined as having a single root $(P P H$ 1.6.6), being evergreen $(P P H$ 1.9.4), having fleshy leaves $(P P H 1.10 .4)$ and bearing fruits both on the top and at the sides $(P P H$ 1.14.2). Time of sowing is after the summer solstice, in the month of Metageitniōn (July) (PPH 7.1.2-3). It is propagated by a piece torn off but it is essential to take a piece which has roots attached to it ( $P P H 7.2 .1)$. The plant shoots again if the stem is broken and the regrown stem is sweeter, provided the leaves are stripped off before the plant runs to seed $(\mathrm{PPH}$ 7.2.4). The belief of the antagonism between rhaphanos and grape is explained by the effect of the smell of rhaphanos on the vine, which is infected by it. In parallel, this fact would explain the use of rhaphanos against drunkenness ( $P P H$ 4.16.6).

Fragments from writers of the II century B.C.E. are given by Athenaeus (Deip. 9.9): NicAnder in his Geōrgika [Georgics] mentioned smooth-leaved and curly-leaved krambe , as well as a purple-colored type (epifoinissousa) and possibly one from Kymē..$^{11}$ Also the wild type is mentioned. Descriptions of different types of krambe were also reported by EuDEMus (Euthydemus of Athens) (probably II century B.C.E.), who listed in his Peri lachanōn [On vegetables] a smooth-leaved type which grows everywhere, a celery-like type which owes its name to the curliness of the leaves, and a maritime type. The locations where these grew are also mentioned, being on Greek islands (Eretria, Kymi, Rhodes) or on the Anatolian coast (Knidos and Ephesus).

The descriptions made by the physician Pedanius DiosCorides in his Peri ylēs iatrikēs $(P Y I)$, also known as De Materia Medica [On medical matters], written about the year 65 C.E., report three types of krambe, that is hemeron (domestic), agrion (wild) and thalassia (maritime). The domestic type is suggested as a remedy

\footnotetext{
11 Apart from the uncertainty mentioned above, an alternative interpretation is given in Canfora (2001), that kyme in this text could be equivalent to kyma, in the sense of cole's young sprouts.
}

for all sorts of diseases, ranging from trembling, poor vision, pain, ulcers, gangrene, inflammation, hair loss, spleen disease, worms, and it is also efficacious against viper bite and drunkenness. The wild species is said to grow in coastal places and rocks and to be similar to the domestic one, but whiter, hairier and more bitter. Leaves are useful to cure wounds and inflammation. The description of a third one (krambe thalassia or maritime) does not correspond to a Brassica species, as reviewed by Matthioli and others, see Discussion below (DiOsCorides, PYI 2.146-147).

$K r a m b \bar{e}$ is frequent also among the recipes of Aretaeus of Cappadocia, one of the most celebrated of the ancient Greek physicians, who probably practiced in the I century C.E. at the time of Nero or Vespasian, in his works Oxeōn nousōn therapeutikon (On the therapeutics of acute diseases) 1.3; 2.1 and Kronion nousōn therapeuticon (On the cure of chronic diseases) 1.2; 1.4; 2.7 (Adams 1972).

Galen, physician of the II century C.E. from Pergamon, discussed the medicinal properties of the cole in De simplicium medicamentorum temperamentis ac facultatibus [On the mixtures and properties of simple drugs] (12.43), where he listed the same three types mentioned by DiosCorides. He also mentioned kyma as young sprouts of cole (krambē) in De alimentorum facultatibus [On the properties of foodstuffs] (6.642).

LuCian of Samosata, satirist of the II century C.E., in his Verae Historiae [A True Story], section 23, tells a story of a krambe tail growing on the back of people living on the comets.

Diogenes Laertius (ca. III century C.E.), in his Biōn kai gnōmōn tōn en philosophiai eudokimēsantōn [Lives and Opinions of Eminent Philosophers] (2.17), wrote a simile comparing the flavour of krambe with radish.

Other indications of Greek knowledge of coles and their medicinal uses can be found in the Latin writers Cato and Pliny, who must have been able to read books by Greek authors, including illustrated herbals that have not reached the present day (see below, PLINY THE ELDER).

\section{References related to Egypt (Greco-Roman times)}

The use of coles in Egypt is documented for GrecoRoman times by Greek, Demotic and Coptic texts. For example the Hibeh Papyri (1.121), written in Greek 
around 250 B.C.E., contain a private account, probably rendered by a servant to his master, of expenditure for various purposes, including krambe, which cost 4 oboloi. The Oxyrhynchus Papyri (12.1479), written in Alexandria between 25 and 1 B.C.E. speaks of a decoction of krambe (krambēin). A demotic medical papyrus (Wien D 6257, IV, 6) of the II century C.E. describes a recipe including coles $(\mathrm{grmb})$ to treat a disease of the esophagus (Reymond 1976).

According to Athenaeus who lived in Egypt in the III century C.E., the custom among the Egyptians to eat boiled krambe before a meal was proof that they loved to drink wine (Deip. 1.62). The same author mentioned a fragment by Diphilus from Siphnos (342-291 B.C.E.), who said that seed imported from Rhodes to Alexandria generated sweet krambe during the first year, but in the following generations the plants would become too bitter due to the 'bitterness' of the soil. According to PLINY THE ELDER (I century C.E.), brassica was never eaten in Egypt, on account of its extreme bitterness ( $\mathrm{NH} \mathrm{20.91).}$

Amélineau (1894) reports on a Coptic text that was part of Historia Lausiaca [The Lausiac History], written by Palladius of Galatia, Bishop of Helenopolis in Bithynia in the year 420 C.E. A chapter on the life of Macarius of Alexandria describes the extreme ascetic behavior of this monk who lived in Egypt in the IV century C.E. During Lent, the old Macarius did not sit, did not eat bread or drink water and did not kneel, but every Sunday he just took a few leaves of jarambo (Coptic word for coles, from the Greek krambēe).

\section{Latin literature}

\section{The earliest Latin works of the II century B.C.E.}

Titus Maccius Plautus' comedy Pseudolus has been approximately dated to 191 B.C.E. (Sedgwick 1930). A cook being hired boasts that he is not one of those cooks feeding people just with 'grass', as if they were oxen. In the list of such despised herbages, brassica is listed together with fennel, garlic, spinach, etc. (Plautus, Pseudolus, Act 3, Scene 2).

The work De Agricultura (Agr.) [On Agriculture] ${ }^{12}$ by Marcus Porcius CATO, dated ca. 160 B.C.E., is the earliest available entire work of Latin prose. It was

\footnotetext{
12 Translations from CATO are based on Hooper and Ash (1934) and on Canali and Lelli (2000).
}

probably intended as a practical manual for private use, containing all sorts of directions for the farm owner. A long section on brassica (Agr. 156-157) looks like a stand-alone short treatise where the structure, style, language and content are clearly influenced by the earlier Greek botanical and medical traditions (Boscherini 1970).

Brassica is described as a vegetable that is superior to any other, being a panacea for all types of diseases. The plant is used either cooked or raw, dipped in vinegar. It promotes digestion and is a laxative. The preparations described by CATO focus more on its healing properties than its culinary purposes. It can be prepared in bunches and boiled, after which the extracted juice should be drunk, or the boiled brassica itself or its broth are used. It can also be ground and applied to wounds, swellings and sores. It is considered very healthy when eaten cut into pieces, washed, then dried and seasoned with salt and vinegar, and it is even tastier with rue and chopped coriander and salt. Bathing in the urine of a person who eats brassica is recommended, especially for children, so that they do not grow weak and puny. Suffumigation of women's privates with this urine boiled in a pot is ideal to facilitate menstruation. Special treatments are listed for those who suffer from colic, strangury, breast cancer, swollen spleen, painful heart, liver, lungs, and any internal illness, including headache and eyeache. It is also suitable to cure arthrosis, sleeplessness, debilitation, but also ulcers, nasal polyps, deafness, malignant scab and more. A purgative recipe includes among its ingredients also two young stalks of brassica (brassicae coliculos duos). Brassica is suitable to allow heavy drinking with no consequences:

Ubi cenaveris, comesto aliqua $V$ folia: reddet te quasi nihil ederis, bibesque quantum voles - CAто, Agr. 156.1

[After dinner, eat some half a dozen leaves; it will make you feel as if you had not dined, and you can drink as much as you please.]

Besides all this, it is a cheap remedy:

Nullus sumptus est: et, si sumptus esset, tamen valetudinis causa experitus - CAто, Agr. 157.8 [There is no expense involved; and even if there were, you should try it for your health's sake]

CAто describes three types (Agr. 157.1-2): 
1. Levis [smooth]. This is large, with broad leaves and a thick stem; it is hardy and has great potency.

2. Apiacon [like celery]. This is a curly type, with a good nature and appearance, and has stronger medicinal properties than the variety mentioned above.

3. Lenis [mild], with small stalk, tender, and the most pungent of all and its juice, though scanty, has the most powerful effect.

A wild variety (brassica erratica) is also mentioned, which is said to have the greatest strength, being able to heal people whom you despair of healing.

Section 157 of the book deals with Pythagoras' brassica (brassica pythagorea). This is not considered an additional variety, as explained in the Discussion below.

\section{Writers of the I century B.C.E.}

Marcus Terentius VARRo (116-27 B.C.E.) was a Roman scholar and writer who wrote more than 400 pieces in his lifetime, of which only two extant works remain: one is on the Latin language and the second is De Re Rustica (RR) [On Agriculture]. ${ }^{13}$ In this book, the quotations from THEOPHRASTUS and CATO about the effects of brassica against drunkenness are reported again ( $R R$ 1.2), as well as the repulsion between grape and brassica (RR 1.16). Brassica is said to require rich and thoroughly worked soils $(R R 1.23 ; 1.43)$. Regarding the importance of the age of the seed, VARRO reports that "from the planting of old brassica seeds it is said that rapa grows, and on the other hand that brassica grows from old rapa seed." (RR 1.40). Brassica is said to offer food and wax to the bees, in a similar way to faba (faba bean), apiaster (balm) and cucurbita (bottle gourd) (RR 3.16).

In his De Natura Deorum [On the nature of the Gods $],{ }^{14}$ Cicero (106-43 B.C.E.), one of the greatest of the Latin orators and prose writers, discussed the Greeks' theories of God and religion. When attempting to prove the existence of the divine, a number of details are introduced in connection with astronomy, animal and plant life, and the physiology of man. It is

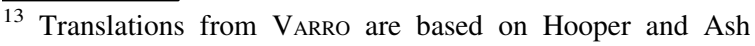
(1934)

14 Translations from CicERo by Brooks (1896).
}

in this context that the Greek belief about the antagonism between brassica and vine is included:

quin etiam a caulibus brassicae, si propter sati sint, ut a pestiferis et nocentibus refugere dicuntur nec eos ulla ex parte contingere.

- Cicero, De Natura Deorum 2.47

[Indeed, it is even said that if brassicae have been planted near them, the vines shrink from them as from something deadly and injurious, and come nowhere into contact with them.]

VIRGIL (Publius Vergilius Maro), (70-19 B.C.E.), one of Rome's greatest poets, author of the epic poem the Aeneid, also wrote minor poems. In one of these, the cole (holus), is depicted in a poetic verse:

Hic holus, hic late fundentes bracchia betae — VIRGIL, Moretum 72

[And here was cabbage, here were beets, their foliage extending wide]. ${ }^{15}$

Horace (Quintus Horatius Flaccus) (65-8 B.C.E.), leading Roman lyric poet during the time of Augustus, makes use of coles (caules) in his Satirae (Satires) on various occasions to illustrate with metaphors human behaviors and philosophies. HORACE criticizes as distorted the idea of absolute ethics, which considers that all sins are equal. To give an example, he says that the $\sin$ of breaking the stalks of the coles in a neighbor's garden cannot be given the same weight as stealing by night things consecrated to the gods (Satira 1.3.116). In another Satire the character of a stingy person is represented by a man who dresses his coles with rancid, smelly oil (Satira 2.2.61). Finally, coles growing in dry lands are thought to be sweeter than those grown about town, since nothing is more insipid than a much watered garden (Satira 2.4.15). ${ }^{16}$

Sextus Propertius (ca. 50-ca. 15 B.C.E.), the elegiac Latin poet, celebrated in a poem Vertumnus, an ancient god of Etruscan origin, whose statue was placed near the Roman forum. ${ }^{17}$ This elegy is probably intended to mark the successful melding of Roman and Etruscan people, in line with the Augustan policy of

\footnotetext{
15 Translation from VIRGIL by Mooney (1916).

16 Translation from Horace based on Smart and Buckley (1863).

17 In Roman mythology, Vertumnus is the god of seasons, change and plant growth, gardens and fruit trees (Wikipedia http://en.wikipedia.org/wiki/Vertumnus).
} 
conciliation between Romans and other Italic people. Vertumnus is described holding in his hands the best products from the vegetable garden (hortorum dona probata): cucumbers, bottle gourds and coles ( $\mathrm{cu}$ cumis, cucurbita and brassica). These brassicas are tied with light cords made of rushes (Elegiae [Elegies] 4.2.44). ${ }^{18}$

Aulus Cornelius Celsus (25 B.C.E.-50 C.E.) was an encyclopedist and possibly, but improbably a physician who probably lived in Gallia Narbonensis, the current Languedoc and Provence, in southern France. His work De Medicina (Med.) [On Medicine $]^{19}$ is the only surviving section of a much larger encyclopedia and is one of the best sources on medical knowledge of his time. Brassica is mentioned several times. As a food, together with beets and leeks, it is considered, among the vegetables, more nutritious than lettuce, gourd or asparagus (Med. 2.18.5). However, it is also listed among the materials that have 'bad juice', meaning that it is indigestible, and its sprouts (cyma) even more so (Med. 2.21), it is 'acrid' (Med. 2.22) and produces flatulence (Med. 2.26). It moves the bowels if not well cooked (Med. 2.29), while the bowels are blocked if it is twice boiled (Med. 2.30). As a cure for diseases, brassica leaves are listed among the medicaments that simultaneously repress and cool (Med. 2.33). Finally, pounded seeds of brassica can be given as a remedy against round worms, which especially trouble the children (Med. 4.24).

\section{Columella (I century C.E.)}

Lucius Junius Moderatus Columella (4-ca. 70 C.E.), born in Gades, current Cadiz, Spain, was a military officer of the Roman Legion and became landowner of various farms in Italy. He specifically refers to his properties located at Cere, Ardea, Carseoli and Alba. His De Re Rustica (RR) [On Agriculture $]^{20}$ in twelve volumes has been completely preserved and is one of the most important sources on Roman agriculture. He used many sources, such as CATO and VARRO, but also others that are no longer extant, including Cornelius Celsus and many Greek sources. His works were

\footnotetext{
18 Translation from Propertius based on Kline $(2002,2008)$.

19 Translation from CELsus based on Spencer (1935).

20 Translation from Columella based on Forster and Heffner (1954) and on Calzecchi Onesti (1977).
}

written between 60 and 65 C.E. and include several references to coles, with the first names of local varieties, cultivation practices and medicinal uses. In the sixth book, which deals with farm animals, brassica is mentioned as a remedy against various ailments. Thirty moderate-sized stalks of brassica cooked and dipped in vinegar (triginta brassicae modicae caules cocti et ex aceto dati) can be used as a remedy for indigestion of oxen ( $R R$ 6.6.1); while as a remedy against fever, oxen should be made to swallow thirty cooked stalks of brassica of moderate size which have been dipped in oil (coctos brassicae coliculos triginta) (RR 6.9.1). Raw brassica is to be administered if a mule is on heat (equienti mulae cruda brassica datur) (RR 6.38.1). Books 10 and 11 are about the cultivation of home gardens and we learn that brassica belongs to those plants (together with lettuce, artichoke, rocket, etc.) that can be sown in two different seasons, spring and fall ( $R R$ 11.3.14). Once this crop is sown, the soil turns green all over and offers coles (caules) during the winter and sprouts (cymata) in spring, equally to the poor man and to the arrogant king (pariter plebi regique superbo frigoribus caules et veri cymata mittit) (RR 10.127). Columella lists 12 types of caules, mainly distinguished on the basis of the locality where they were grown:

1. Quae pariunt veteres caeposo litore Cumae [Those from Cuma, growing on the coast which is also rich in onions]

2. Quae Marrucini [Those from the Marrucini]

3. Quae Signia monte Lepino [Those from Signa on Mount Lepino]

4. Pinguis Capua [Those from fertile Capua]

5. Caudinis faucibus horti

[Those from the gardens of the Caudine gorges]

6. Fontibus et Stabiae celebres et Vesbia rura doctaque Parthenope, Sebethide roscida lympha

[Those from Stabia, famous for its springs, the Vesuvian countryside and for the learned Naples, which is irrigated by the Sebeto river]

7. Quae dulcis Pompeia palus vicina salinis Herculeis vitreoque Siler qui defluit amni [Those from the sweet marsh of Pompeii, close 
to the salt-mines of Hercules and the river Sele, which flows with limpid waters]

8. Quae duri praebent cymosa stirpe Sabelli

[Those sprouting types produced by the tough Sabellians]

9. Turni lacus

[Those from Lake Turno]

10. Pomosi Tiburis aeva

[Those from the fruitful fields of Tivoli]

11. Bruttia quae tellus

[Those from the Bruttium land]

12. Mater Aricia porri

[Those from Aricia, motherland of leeks] ${ }^{21}$

-Columella, RR 10.130-139

Other passages in the poetic Book 10 tell us about the growth cycle of brassica, explaining that when brassica's stem gets stronger (cum valido pinguescit...caule brassica), it is the time that snails and bugs come to eat it and moreover often Zeus pours down furious rain and hail ( $R R$ 10.325-330). The time when the first coles (caules) are ready is the same for lettuce, leeks and celery to be ready ( $R R$ 10.369). Book 11 gives us a detailed technical description of the cultivation practice: brassica has to be transplanted at a six-leaf stage by first dipping its roots in liquid manure and then digging it into the ground, wrapped into three small bands of algae. In this way, it will quickly get softer when cooked and will conserve its green color even without salt. In cold and rainy areas the best time to plant it is after the Ides of April; when plants have recovered, they get stronger if weeded and manured, as much as possible, so that they will grow a larger stem and sprouts. In warmer places coles can be planted after the Calends of March; however, most of them immediately go to flower and then, during the winter, once cut back, they no longer give a large stem. When the stem is very large, it is possible to transplant up to twice and they say that seed is thus more abundant and larger (RR 11.3.23).

\footnotetext{
${ }^{21}$ Cuma, Capua Stabia, the Caudine gorges and Lake Turno are locations in present-day Campania; the Marrucini were an Italic tribe living on the north coast of Abruzzo; the Lepini mountains are in Southern Lazio; Tivoli and Ariccia are localities in Lazio; the Sabellians were a group of tribes living in northern Lazio; Bruttium is today's Calabria.
}

Book 12 is dedicated to the housewife and to recipes and methods for conserving food. By the time of the spring equinox, sprouts and coles (cymam, caulem) can be harvested and conserved under vinegar and brine ( $R R$ 12.7.1). They need to be dried in the house for many days, until they wither and then they are put in jars under two parts of vinegar and one part of brine (RR 12.7.5).

\section{PLINY THE ELDER (I century C.E.)}

Gaius Plinius Secundus, (23-79 C.E.), better known as Pliny the Elder, born in Como, was a naval and military commander as well as a writer of science and history. His only writing to have survived to modern times is the Naturalis Historia $(\mathrm{NH})$ [Natural History $^{22}$ which is an encyclopedic collection of the knowledge of nature in his time. This work in 37 books was completed in the year 77 C.E. and dedicated to the emperor Titus Flavius Vespasianus. Pliny studied the original authorities on each subject and made an effort to compile the various excerpts, sometimes, however, without a sufficiently critical reading. For example, in Book 19 he reported THEOPHRASTUS' notes on the cole (rhaphanos in TheOPHRASTUS) as if they were referring to radish (raphanus in Latin) ( $N H$ 19.80). Therefore he pointed out, possibly based on this misunderstanding, that the coles, in his present day the main products of a vegetable garden, were not in high praise among the Greeks (NH 19.136). However, in Book 20, PLinY reported at length to what extent brassica was esteemed by ancient Greek authors, among them Chrysippus, Dieuches and Pythagoras, who dedicated entire volumes (none of them reaching the present) to this subject (NH 20.78). He also repeats the three types that were traditionally described by the most ancient Greek authors, i.e. in his words: (1) the 'curly' one, that was called selinada, due to the resemblance of its leaves to celery (crispam, quam selinada vocaverunt a similitudine apii foliorum), beneficial to the stomach, and moderately relaxing to the bowels; (2) lea, with broad leaves running out from the stalk, whereby some persons have given it the name of caulodes (leam, latis foliis e caule exeuntibus, unde caulodem quidam vocavere), of no use whatever from a medicinal point of view; (3) crambe proper, with thinner leaves, of

\footnotetext{
22 Translations from Pliny THE Elder based on Bostock and Riley (1855) and on Aragosti et al. (1985).
} 
simple form, and closely packed (proprie appellata crambe, tenuioribus foliis et simplicibus densissimisque), more bitter than the others, but extremely efficacious in medicine.

In his introduction to the Roman home garden, PLINY remarked that new fruits were created, inaccessible to the poor, with new tastes or larger sizes and monstrous traits. Among these, a cole that grows so big (caule saginato) that a poor man's table would not be large enough to hold it ( $N H$ 19.54).

PLinY notes that CATO spoke in high praise of garden coles (caules). However, these were not esteemed in those days as much as they were at the present time, since they required additional dressing (oil) to have a good taste, while the objective at the time of CATO was to economize oil as much as possible ( $N H$ 19.57).

He then quotes the three varieties distinguished by Cato, using similar words (see Table 1).

Notions about coles' cultivation and use, including the practice of using sprouts (cymae), is then described by PLiny. They may be sown the whole year round, and they are cut at all periods of the year. "The best time, however, for sowing them is at the autumnal equinox, and they are usually transplanted as soon as five leaves are visible. In the ensuing spring after the first cutting, the plant yields sprouts (cymae). These sprouts are small shoots thrown out from the main stem, of a more delicate and tender quality than the cole itself. The exquisite palate, however, of ApIcIus rejected these sprouts for the table, and his example was followed by the fastidious Drusus Caesar" who was for this reason criticized by his father Tiberius. "After the cymae have made their appearance, the cole throws out its summer and autumn shoots, and then its winter ones; after which, a new crop of cymae is produced, there being no plant as productive as this, until, at last, it is quite exhausted by its extreme fertility. A second time for sowing coles is immediately after the vernal equinox, the plants of this growth being transplanted at the end of spring, that they may not run up to cyma before growing the stem (ne prius cyma quam caule pariat). A third sowing takes place about the summer solstice, the transplanting being done in summer if the soil is moist, but, if too dry, in autumn. When moisture and manure are supplied in small quantities, the flavor of the cole is all the more agreeable, and when they are supplied in greater abundance, the plants attain a larger size. Ass dung is the most suitable for its growth" (NH 19.137-138).
The effects of cold on coles are also described, with frost largely contributing to their sweetness. A number of varieties are then described with morphological details (NH 19. 139-141):

1. Trizianum or Tritanum (graphic oscillation depending on the manuscript)

[Tritian]

Rather than a variety, this name seems to indicate the result of a whitening cultivation practice. Here is the text of PLINY:

To obtain plants equally remarkable for their size and flavor, care must be taken first of all to sow the seed in ground that has had a couple of turnings up, and then to follow up the shoots as they appear above ground by molding them up, care being taken to throw up the earth over them as they increase in luxuriance, and to let nothing but the summit appear above the surface. This kind is known as the Tritian caulis: in money and labor it costs twice as much as any of the others.

\section{Cumanum}

[From Cuma]

It has sessile leaves and a wide, open head (sessile folio, capite patulum)

3. Aricinum

[From Aricia]

It is of no greater height, but with more numerous and thinner leaves (altitudine non excelsius, folio numerosius quam tenerius). This is considered the most useful of them all, for beneath nearly all of the leaves there are small shoots (cauliculis) thrown out, peculiar to this variety.

4. Pompeianum

[From Pompeii]

It is considerably taller, the stalk, which is thin at the root, increasing in thickness as it rises among the leaves, which are fewer in number and narrower (procerius, caule ab radice tenui, intra folia crassescit; rariora haec angustioraque). The great merit of this caulis is its remarkable tenderness, although it is not able to stand the cold.

5. Bruttiani

[From Bruttium]

It thrives all the better for cold; its leaves are remarkably large, the stalk thin, and the flavor 
Table 1 Parallelism in the description of cole types (IV century B.C.E.-I century C.E.)

\begin{tabular}{|c|c|c|c|c|c|}
\hline $\begin{array}{l}\text { AuTHOR } \\
\text { Period and source }\end{array}$ & Crop name & Smooth & Curly & Mild & Wild \\
\hline $\begin{array}{l}\text { ThEOPHRASTUS } \\
\text { IV cent. B.C.E. } \\
\text { PPH } 7.4 .4\end{array}$ & Rhaphanos & Leiophyllos & Oulophyllos & & Agria \\
\hline $\begin{array}{l}\text { NICANDER } \\
\text { II cent. B.C.E. } \\
\text { Deip. } 9.9\end{array}$ & Krambē & Lei $\bar{e}$ & Oulē & & Agrias \\
\hline $\begin{array}{l}\text { EuDEMUs } \\
\text { (Euthydemus of Athens) } \\
\text { ca. II cent. B.C.E. } \\
\text { Deip. } 9.9\end{array}$ & Krambēe & Leiophyllos & Selinoussa & & Halmyris \\
\hline $\begin{array}{l}\text { САто } \\
\text { III-II cent. B.C.E. } \\
\text { Agr. 157.1-2; } 12\end{array}$ & Brassica & Levis & Crispa (Apiacon) & Lenis & Brassica erratica \\
\hline $\begin{array}{l}\text { PLINY THE ELDER } \\
\text { I cent. C.E. } \\
\text { (reporting about CATO) } \\
\text { NH } 19.41 \\
\text { NH } 20.36\end{array}$ & Brassica & $\begin{array}{l}\text { Extentis foliis, } \\
\text { caule magno }\end{array}$ & Apiaca & $\begin{array}{l}\text { Minutis caulibus, } \\
\text { lenem, teneram } \\
\text { minimeque }\end{array}$ & $\begin{array}{l}\text { Silvestris sive } \\
\text { erratica }\end{array}$ \\
\hline $\begin{array}{l}\text { PLINY THE ELDER } \\
\text { I cent. C.E. } \\
\text { (reporting about very ancient Greeks) } \\
\text { NH } 20.33 .9 \\
\text { NH } 20.37\end{array}$ & Brassica & Lea & Selinada & Crambe & Brassica marina \\
\hline
\end{tabular}

pungent (praegrandes foliis, caule tenues, sapore acuti).

6. Sabellico

[Sabellic]

The leaves are crisp to such a degree as to excite our surprise, and their thickness is such as to quite exhaust the stem (usque in admirationem crispa sunt folia, quorum crassitudo caulem ipsum extenuet, sed dulcissimi perhibentur ex omnibus). In sweetness it is said to surpass all the others.

7. Lacuturnenses ex convalle Aricina [From the Lake Turno area in the Aricia valley] The head of this caulis is very large, and the leaves are almost countless, some of them being round and smooth, and others long and sinewy (capite praegrandes, folio innumeri, alii in orbem conlecti, alii in latitudinem torosi). These have lately come into fashion and indeed, there is no caulis that runs to a larger head than this, with the sole exception of the Tritian type, which has a head sometimes as much as a foot ${ }^{23}$ in thickness, and throws out its cymae the latest of all.

The list is completed by another type known by the name of halmyridion (saltish), since it grows only on the sea-shore and which never exceeds the height of an herbaceous plant. Finally, a kind of wild sprout (cyma silvestris) is also described and called lapsana, but not to be referred to a cole (see "Discussion" below).

The medicinal properties of brassica are mainly dealt with in Book 20 of the Natural History, with reference to the same Greek authors that might have been the source for CATO and to CATO himself. The

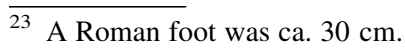


medicinal uses and preparations according to CATO are summarized, as well as the opinions of the Greek physicians on the medicinal use of brassica, in addition to the points already touched by CАTO (NH 20. 84-91). Quotations are given from HIPPOCRATES and other physicians, such as Epicarmus (VI-V centuries B.C.E.), Apollodorus, Erasistratus and Philistion (III century B.C.E.), whose original works have not survived, other than a few fragments. According to PLINY, the Greeks were of the opinion that brassica carried off bile, was astringent and very beneficial to the stomach, the sinews and the eyesight. It cleared the senses and was to be prescribed to the paralytic and nervous, as well as to people affected with spitting of blood. It was good for dysentery, coeliac affections and diseases of the kidneys; it increased the quantity of the milk in women who were nursing, and promoted menstrual discharge. It was also efficacious in expelling a dead fetus and to be taken in cases of poisoning by fungi, and for hiccups, dimness, leprosy, snake bites, hair falling and more. It was to be taken raw or boiled, as a juice of the stalk or of the root. Alternatively, the leaves or stalk could be dried and ground into a powder. Seeds were also employed. Brassica could be applied topically as a liniment and could be mixed with salt, vinegar, barley-meal, rue, coriander, aniseed, fenugreek, honey and pepper, depending on the specific treatment and preparation.

The medicinal properties of the wild type were similarly wide-ranging and even more efficacious $(\mathrm{NH}$ 20.92-95), including against insanity (NH 26.118). Wild brassica is here said to be called petraea by some people, which means 'of the rocks'. It is described as a plant having small, rounded, smooth leaves and bearing a strong resemblance to the cultivated cole, but whiter and hairier (NH 20.93). A so-called brassica marina (sea kale) is also mentioned, with no description, for its purgative effect and pungent taste (NH 20.96).

The natural enmity between brassica (cultivated or wild) and the grape is repeated by PLINY several times (sometimes erroneously referred to as a radish, due to his misunderstanding of THEOPHRASTUS) (NH 17.240; $19.87 ; 20.84 ; 20.92 ; 241$ ). Similarly, the corresponding preventive or curative effect against drunkenness is highlighted:

Vino adversari ut inimicam vitibus, antecedente in cibis caveri ebrietatem, postea sumpta crapulam discuti.
- Pliny the Elder, NH 20.84

[As there is a natural enmity between it and the vine, it combats the effects of wine; that, if eaten before drinking, it is sure to prevent drunkenness, being equally able to dispel crapulence if taken after drinking.]

Of all types of brassica, the most agreeable to the taste are said to be the young inflorescences, cyma, although no use is made of them in medicine ( $N H$ 20.90).

A few evil qualities of the cole are also reported, since the water in which it has been boiled gives off a very bad smell ( $N H$ 20.90). When eaten, coles make the breath smell, and are injurious to the teeth and gums (NH 20.91).

\section{Other authors of the I century C.E.}

Ovid (Publius Ovidius Naso, 43-18 C.E.) was a Roman poet best known for the Metamorphoses, one of the most important sources of classical mythology. Coles make their appearance in his book, when Baucis and Philemon offer pork slices and freshly cut cole leaves (holus foliis) to the disguised guests Jupiter and Mercury (Metamorphoses 7.647).

Other I century writers use the words brassica, caules or crambe to create allegories in satires and epigrams. Various examples can be found in JuvENAL (Decimus Iunius Iuvenalis, ca. 54-ca. 127 C.E.) (Satirae $1.134 ; 5.87 ; 7.150$ ) and one is reported here:

Cum furem nemo timeret caulibus et pomis, et aperto viveret horto

[There was a time when nobody expected their apples and coles to be stolen by thieves and the gardens were left open]

- Juvenal, Satira $6.18^{24}$

Aulus Persius Flaccus (34-62 C.E.), a Roman poet and satirist of Etruscan origin, was a critic of the excesses of his contemporaries:

nunc nunc inpensius ungue, ungue, puer, caules [Souse the coles, boy, souse them with oil and don't mind the expense] Persius, Satira $6.69^{25}$

\footnotetext{
$\overline{24}$ Translation from Juvenal based on Barelli (2004).

25 Translation from Persius by Conington and Nettleship (1893).
} 
In the context of this satire, this is an exhortation not to deprive your own life under pressure from your heirs, who would prefer you not to spend your money. Therefore, even if good olive oil is expensive, you should not refrain from abundantly seasoning your coles with it. A similar allegory had been used by HORACE in the previous century (Satira 2.3.125).

In the Epigrammata [Epigrams] ${ }^{26}$ of MaRTIAL (Marcus Valerius Martialis, ca. 40-102 C.E.), the coach of Bassus, full of vegetables, passes through the Porta Capena, the gate leading from Rome to the Appian Way. The poet is making fun of landowner Bassus, since his coach is going in the wrong direction. Indeed, Bassus is not bringing the products of his fields into town for sale, but on the contrary, he is leaving town after having bought at the city market everything he needed. This is because his beautiful countryside villa remained sterile of fruits. The coach is carrying leeks, lettuce, beet and 'noble luxuriant coles' (frutice nobili caules) (Epigrammata 3.47.7).

The same author often mentions the coliculi (Epigrammata $5.78 .7 ; 13.17 .1 ; 14.101$ ), i.e. tender shoots that were sold in bunches (fascis coliculi) (Cerchiai Manodori Sagredo 2004).

The Carmina priapea is a collection of anonymous poems from the I century C.E., dedicated to the phallic god Priapus (Mori 2015). In one of these poems (51.14), the owner of a home garden complains that thieves visit only his garden, although the products, including beets and coles, are not more glorious than those in any neighboring garden (non brassicarum ferre glorior caules betasve).

A scratched inscription on a white-painted wall in the atrium of House 6.14.37 in Pompeii, runs $G$. Hadius Ventrio eques natus Romanus inter beta et brassica [Gaius Hadius Ventrio, knight, was born a Roman citizen between a beet and a cole]. This is considered a joke, where this Hadius, with the nickname Ventrio (from venter, 'belly'), was mocked for having risen to his current rank from a humble beginning (Milnor 2014).

\section{Authors of the III-VI centuries}

The Edictum de pretiis rerum venalium [edict on maximum prices] published by the Emperor

\footnotetext{
$\overline{26}$ Translations from Martial based on Ker (1919).
}

Diocletian in 301 C.E. established that the price of five best quality young stalks (coliculi) or a bunch of best quality cymae should not exceed 4 denarii. $^{27}$

De re coquinaria [On the subject of cooking] was the Latin title given to early editions of a Roman cookbook, which is thought to have been compiled between the III and the V centuries C.E. It is a collection of recipes of various origins and times that were used for the Roman patrician cuisine. It contains a certain number of recipes that were originally written possibly by Marcus Gavius ApIcIUs, a notorious Roman gourmet and lover of luxury who lived in the I century C.E. at the time of the emperor Tiberius. The third book contains six recipes on Cimas et coliclos. The young stalks and leaves are boiled or stewed and seasoned with oil or wine and other herbs:

Coliculos elixatos mediabis, summa foliarum teres cum coriandro, cepa, cumino, piper, passo vel careno et oleo modico.

[Cut the stalks in half and boil them. The leaves are mashed and seasoned with coriander, onion, cumin, pepper, raisin wine, or condensed wine and a little oil.] (tr. by Vehling 1936)

$$
\text { — APICIUs, De re coquinaria 3.9.2 }
$$

Quintus Sammonicus SerEnus, a Roman author of the III century C.E., collected in a medical poem a number of remedies, some of them borrowed from PLiNY and DiosCORIDES, and various magic formulae, amongst others the famous 'Abracadabra', as a cure for fever and ague. The use of brassica and caules is mentioned in various remedies against dysentery, cholera, snake bites and others (Liber medicinalis [The Medical Book] 13.196; 15.277; 16.291; 18.333; 28.537-56; 36.699; 45.831).

In the Epitome de Caesaribus [A booklet about the style of life and the manners of the imperatores], written around 361 C.E. by Sextus Aurelius Victor, historian and politician, a famous account is given about the retirement of Diocletian to his palace in Dalmatia, near the administrative center of Salona on the Adriatic Sea (near today's town of Split, Croatia). He was the first Roman Emperor to voluntarily remove himself from office and take up his beloved hobby of growing vegetables (olera, usually translated as 'cabbages' in English translations). However, use of olera

\footnotetext{
$\overline{27}$ See item VI. de oleribus et pomis in Lauffer (1971).
} 
may have simply meant gardening (which probably would have included coles) rather than the specific crop. The reply of Diocletian to Herculius and Galerius, soliciting him to resume control, remains a hymn to the beauty of gardening (coles), in the words of Aurelius Victor:

Utinam Salonae possetis visere olera nostris manibus instituta, profecto numquam istud temptandum iudicaretis.

[If you could see at Salona the vegetables/coles raised by our hands, you surely would never judge that a temptation.]$$
39.6^{28}
$$ \\ -Aurelius Victor, Epitome de Caesaribus}

Palladius (Palladius Rutilius Taurus Aemilianus), a Roman author of the IV century C.E., wrote a treatise on farming, Opus agriculturae (Op. agr.) (sometimes known as De Re Rustica), that obtained some celebrity and was well known in the Middle Ages. This treatise, in 14 parts or books, gives detailed instructions, month by month, for the typical activities of a year on a Roman farm. It is suggested that coles (caules) be sown in February, although they can be sown at any time of the year (Op. agr. 3.24.5). If brassica is sown in April at the end of the spring, it will produce stems (cauli), since the time for sprouts (cyma) has passed (brassica serere possumus, quae cauli serviet, quia cyma: tempus amisit) (Op.agr. 5.3.1). If sown in June, around the solstice, it is transplanted around the first days of August in a place rich with water or well moistened by rain (Op. agr. 7.4). The most suitable period for sowing brassica is September, with transplanting in November. In this way it will produce sprouts during the winter and spring (tempore hoc brassicam seres utilius, ut plantas eius novembri inchoante transponas: de quibus et hieme olus et vere possit cyma produci) (Op. agr. 10.13). PALladius also mentions that the old seed of brassica becomes rapa (turnip) (Semen brassicae uetustum mutatur in rapa) (Op. agr. 3.24.7). ${ }^{29}$

\footnotetext{
$\overline{28}$ Translation from Aurelius VICTOR based on Banchich (2009).

29 Translation by L. Maggioni.
}

\section{Discussion}

The information collected in a temporal sequence in the above section is re-elaborated in this discussion, bringing together the main themes that have been touched upon in the literature surveyed. We discuss the diversity of types described and possible 'taxonomic' inferences that can be made. Then we discuss the different uses of coles in light of modern medicinal studies and we compare the cultivation practices described by the ancient authors with current ones. We conclude with a few comments and thoughts about the theories of domestication of the coles.

\section{Different types of coles}

Among the available sources, TheOPHRAStus was the first (IV century B.C.E.) to describe three different kinds, the curly-leaved, the smooth-leaved and the wild form. The curly-leaved was preferred for its better flavour. This pattern of three types is repeated by other Greek writers on agricultural subjects, indicating that the only variation recorded by scholars in ancient Greece is related to the shape of the leaves (either curly or smooth). Although the descriptions of TheOPHRASTUS and his followers remain rather scanty, it seems clear that at least a couple of domesticated leafy kales, as well as the wild species (presumably $B$. cretica Lam.) were used at the time. The lack of description of heading types and other forms is an indication that differentiation from the basic leafy kale type had not yet started or did not occur in ancient Greece.

The works of CATO (III-II centuries B.C.E.) were largely inspired by Greek literature and he basically described the same types mentioned by THEOPHRASTUS, Eudemus and NicANDER (one smooth, one crispy or celery-like and a wild or sea-shore type). Both the medical properties and the morphological descriptions seem to be largely of Greek origin, although there is one additional type (Lenis), tender and with a thin stalk, accompanying the traditional curly-leaved (Crispa) and smooth-leaved (Levis) types. Scholars believe that the so-called brassica pythagorea in Cato's De Agricultura (Agr. 157.1) is not a specific variety. This term would be a reference to the belief that original studies of this plant's properties were attributed to Pythagoras or his school, back in the VI century B.C.E. (Boscherini 1970; Canali and Lelli 
2000). Still no mention of heading or other types is made at the time of CATO. By the first century C.E., however, the encyclopedic works written by CoLumella (60-65 C.E.) and Pliny (77 C.E.), testify to an explosion of different forms. Columella distinguishes at least twelve types of coles. Except for one 'sprouty' (cymosa) type, no morphological description is given, but only mention of the location where they were grown. This is perhaps the first example of a 'label' based on a geographic indication of origin. All the coles were growing in central or south Italy (Lazio, Abruzzo, Campania and Calabria). There is also no indication about whether different types of products were consumed, except a distinction made between the primary product (caules), the young stalks (cauliculos) and the sprouts or young inflorescence sprouts (cyma) produced after the plant had been cut back. When Propertius describes the god Vertumnus holding in his hands, among other vegetables, brassicas tied up with light rushes, we can imagine bunches of tied up leaves.

More information is found in Pliny's Naturalis Historia $(\mathrm{NH})$. Initially, PLINY reports the knowledge of CATO (NH 19) and of ancient Greeks (NH 20). Table 1 shows the parallels in the description of the same three or four types with little variation since the writings of THEOPHRASTUS. Indeed, it has been hypothesized that the three authors, THEOPHRASTUS, CATO and PLINY derived their information from an earlier common Greek source (Wellmann 1921 in Boscherini 1970). This pattern raises the doubt that later authors were not describing the reality of their time, but just uncritically reporting previous information. However, in a different part of Book 19 (NH 19.139-141), PLinY for the first time gives a substantial description of varieties of his time, although he only reports on six of the types quoted by Columella. These descriptions cannot be used to clearly match the Roman types with modern forms, but a few traits are described for the first time, showing that variation of forms of cole crops had started by Columella's and PlinY's time. Leaf traits are used to describe Bruttiani (leaves are remarkably large) and Sabellico (the leaves are crisp to such a degree as to excite our surprise). Cumanum and Lacuturnenses clearly develop a head. Cumanum has sessile leaves and a wide, open head (capite patulum). This is reminiscent of a cabbage or a Savoy cabbage type. Lacuturnenses also have a very large head (capite praegrandes), with many leaves (folio innumeri), some of them disposed in a globe shape (alii in orbem conlectii), others long and sinewy (alii in latitudine torosi). In this description we may see a combination of various traits that have subsequently been separated in more modern varieties. The Tritianum variety also has a head sometimes as large as a foot (i.e. $30 \mathrm{~cm}$ ) (pedale aliquando conspicitur). The Aricinum has peculiar small shoots (cauliculis peculiaribus) emerging beneath nearly all the leaves. The Pompeianum has a tall stalk which is thin at the root, increasing in thickness as it rises among the leaves. This description sounds like a marrow-stem kale. When Pliny discusses the monstrosities created by 'modern' agriculture, he mentions some coles that have grown so big (caule saginato) that the poor man's table is not large enough to hold them. This is a rhetorical expression, with no real descriptive value. However, we may be tempted to imagine that he was referring to some type of heading coles, although it is not possible to distinguish whether classical authors were dealing with cabbages or cauliflowers. In the list of maximum prices of vegetables, issued by Diocletian in 301 C.E., cole products were listed with the name coliculos and cymae. As five coliculos had the same value as five pieces of lettuce and as ten large leeks, the term coliculos might have meant in this case entire cole plants, although it is not easy to imagine the shape of this crop. On the other hand, a bunch of cymae could have been anything between tender inflorescence tops and the current broccoli. The same words (cymas $e t$ coliclos) are used in the recipe book of ApIcius, possibly indicating a variety of crop types, ranging from sprouts to heading coles, but the recipes do not allow an easy interpretation of the crop shapes.

\section{References to wild species}

Wild species are mentioned by the Greek and subsequent Latin authors as one of the existing kinds of coles that were used. These were called rhaphanos agria by THEOPHRASTUS and krambē agrias by NICANDER. THEOPHRASTUS describes the wild rhaphanos as having small round leaves and a sharp medicinal taste, used for the stomach. However, the description does not match with the expected morphology of a wild Brassica. In NICANDER, the wild krambe gets in the middle of sown areas and produces many leaves. For EudEMus the wild cole is 'saltish' (krambe almyridos), indicating its habitat being close to coastal areas. CАTO 
calls the wild form brassica erratica and refers to its healing properties, which are stronger than in the cultivated types. For the wild brassica, PuinY uses the adjective petraea (of the rocks) (NH 20.92), halmyridion (saltish) ( $\mathrm{NH} \mathrm{19.142)}$ or marina (maritime) $(\mathrm{NH}$ 20.96), which could be indicative of its habitats. PLINY's descriptions of the petraea type, described with small round leaves, and of the halmyridion, which only grows on the sea-shore, never exceeding the height of a herbaceous plant, indicate that he also, like Theophrastus, possibly mixed up two (or more) different plants. Parts of these descriptions have been interpreted as corresponding to Convolvulus soldanella L. (now Calystegia soldanella (L.) Roem. et Schult.). According to André (2009), this seashore species with small round leaves has nothing to do with the Brassica family, but is still today given local names related to the coles (i.e. chou marin in France or cavolo marino in Italy). The description of halmyridion recalls Crambe maritima L., which however is not distributed in the Mediterranean area. Also the description by DiosCoRIDEs of krambe thalassia (or maritime cole), critically reviewed by Matthioli (1568), does not correspond to a Brassica species, but rather to C. soldanella. On the other hand, the description of the wild cole (krambe agria) of DiOSCORIDES has been interpreted as Brassica cretica (Liddell and Scott 1982; Janick and Hummer 2012). It is possible, however, that DiosCoRides' description of krambe agria as a "whiter, more dense and bitter" (leukotera kai dasutera kai pikra) plant might better correspond to B. incana Ten., if the Greek word dasutera were translated with its alternative meaning of 'hairier', rather than 'more dense'. Indeed, Matthioli (1568), in his translation into Italian, used the word hirsuta, which means 'hairy'.

One last example of confusion about the wild coles is the inclusion by PLINY of lapsana among them: olus silvestre or cyma silvestris (NH 19.44) and silvestres brassicas ( $N H$ 20.96). He says that this type became famous since the triumphs of Julius Caesar, as a consequence of the songs and jokes of his soldiers in which they used to reproach him for having made them live on lapsana at the siege of Dyrrhachium (today's Durres, Albania) ( $N H$ 19.144). There are different interpretations of the possible taxonomy of lapsana. A note in Bostock and Riley (1855) explains that this plant is probably the same as the chara, mentioned by CAEsar in his De Bello Civile [The Civil War] (3.48) and this was variously interpreted as the common parsnip or Crambe tatarica of Hungary, the roots of which are eaten in time of scarcity in the present day, or that it may belong to the Brassica napobrassica of Linnaeus, the rape-colewort.

In conclusion, regarding the wild Brassica species, it can be said that they were listed among the plants still in use. However, nomenclatural ambiguities and poor descriptions do not always allow us to identify the proper taxonomic correspondence of the plants mentioned.

Uses of the coles

The detailed descriptions of the healing properties of both wild and cultivated brassicas made by CATO and repeated by PLINY, are the heritage of the Greek medical tradition, which did not reach us in the original language.

The abundance of references to coles in ancient Greek literature, including in fragments of comedies and poems, testify to familiarity with this crop. The coles appear as possibly ceremonial plants, used in oaths and exclamations, perhaps due to their healing properties. More likely, the word krambe was used to avoid swearing in the name of a god. Alternatively the invocation of krambe (HIPPONAX, [Fragments] 104, $47-49$ West) is interpreted by Kugelmeier (1996) as a parody in which very insignificant things like coles are represented as objects of worship. Greek literature indicates that coles were a simple food, which was evidently very common and usually prepared boiled.

The presence of brassica can be found in the earliest works in Latin comedies (Plautus) as well as in the most ancient Latin prose (САTO). Repeated references to coles, not only in the technical texts of scientific writers, but also their frequent use in comedies, satires and epigrams of I century C.E. writers, indicate that the use and properties of coles were so deep-rooted in Roman tradition that they were able to immediately pass to the reader understandable allegories, proverbs and metaphors.

We learn from CАTO, who was drawing from ancient Greek texts, that the cole was considered a vegetable superior to any other, a panacea for all types of diseases. The medical text of Aulus Celsus describes brassica among the most nutritious vegetables, although it is also listed among the indigestible.

Current perception of the medicinal value of coles does not diverge too much from the ancient tradition. 
The health information services website WebMD (2017) provides lists of affections against which the different brassica vegetables are used: cabbage is used for various stomach conditions, as well as to treat asthma and morning sickness and to prevent osteoporosis; kale is used as an antioxidant and for heart disease, colitis, constipation, Crohn's disease, diabetes, hangover, hot flushes, high cholesterol, loss of vision and wound healing; broccoli sprouts are taken for allergy, asthma and stomach ulcers. Broccoli sprouts have been marketed for over a decade for their promising chemoprotective health effects (Medina et al. 2015; Ushida et al. 2015). Additionally, all coles are used to prevent various types of cancer.

When rating effectiveness of the above uses, based on reputable scientific references and at least one study (in humans), WebMD confirms 'possible effectiveness' only for cabbages relieving breast engorgement (hard, painful breasts) in breastfeeding women when applied to the skin of the breasts. Broccoli used in a beverage together with cabbage and fruit is also rated as 'possibly effective' to reduce 'bad' cholesterol. Regarding all the other effects, WebMD believes that more evidence is still needed to rate the effectiveness of the coles. However, various works have recognized an association between consumption of cruciferous vegetables and a reduction in risk of prostate cancer (Joseph et al. 2004), lung cancer (Spitz et al. 2000) and colorectal adenomas (Lin et al. 1998). Significant improvements were also observed in blood glucose, lipid profile and blood pressure of non-insulin dependent diabetics when their diets were supplemented with broccoli powder (Madhu and Javed 2016).

Expectations of beneficial effects for human health depend on the fact that brassica vegetables are rich sources of many bioactive compounds, including glucosinolates and flavonoids (Podsędek et al. 2006), which are associated with their cancer-preventive activity and anti-oxidant and anti-inflammatory potential (Traka and Mithen 2009). In particular, flavonoids are known to protect against initiation and progression of atherosclerosis and cardiovascular disease (Mageney et al. 2017). The high antioxidant potential of several brassica vegetables has been reviewed by Soengas et al. (2011). Among glucosinolates, the most well-known for potential chemoprotective action is glucoraphanin, a precursor of sulforaphane, which is an inducer of enzymes with anticancer and cytoprotective properties (Guerrero-Beltrán et al. 2012).
Glucoraphanin is the predominant glucosinolate in broccoli and red cabbage (Verkerk et al. 2010). There is accumulating evidence that sulforaphane also exerts beneficial effects on vascular damage in both cell culture and diabetic animal models via antioxidant properties (Yamagishi and Matsui 2016). In studies with extracts from cruciferous vegetables, broccoli, Brussels sprouts, cabbage, cauliflower and kale were among the most inhibitory of tumour cell lines, with Brussels sprouts being the most active with complete inhibition of the proliferation of all tested tumour cell lines (Boivin et al. 2009).

A special place in the ancient literature is reserved to the alleged property of the coles to exert both preventive and remedial action against drunkenness. This was linked to a supposed, likely mythical, antagonism between the grapevine and the coles in the field. The passage of THEOPHRASTUS on this subject summarizes all the existing beliefs and is possibly one of the sources for all subsequent writers who have echoed these persuasions:

They say that the vine scents the rhaphanos and is infected by it. Wherefore the vine-shoot, whenever it comes near this plant, turns back and looks away, as though the smell were hostile to it. Indeed, Androkydes ${ }^{30}$ used this fact as an example to demonstrate the use of rhaphanos against wine, to expel the fumes of drunkenness for, said he, even when it is alive, the vine avoids the smell.

— Theophrastus, $P$ PH 4.16 .6

The usefulness of broccoli, cauliflower, kale, and cabbage as a remedy for a hangover has persisted throughout history as a popular notion, which is still often quoted as a natural remedy, but without scientific support. It is possible to find on the Internet that "they contain enzymes that support liver detoxification". Personally, we documented in Pazzano, Calabria, local people who recounted the antidotal effects against drunkenness of pieces of raw brassica stems and suggesting this remedy with confidence.

The alleged agronomic antagonism between Brassica and Vitis does not seem to be taken into account by farmers, at least on the basis of our experience in Calabria and Sicily, where it is often possible to find

$\overline{30}$ A Greek physician, who preached temperance to Alexander the Great. 
kales intercropped with grapes. Nor did we find scientific accounts investigating this issue, except Novosadyuk (1988) who claimed that cabbage grown with grapevine had inhibitory effects on vine development.

\section{Cultivation practices}

Cultivation practices reported from Greek and Roman literature mainly refer to the time of sowing, with a preference between spring and autumn. This period corresponds to current practices, whereby depending on the geographic area, type of cole crop and precocity of the variety, time of sowing in Italy ranges between March and September. The notation by PLINY and others that coles can be sown all year round is also plausible for south Italy upon consideration that the minimum soil temperature for germination is as low as $4.5{ }^{\circ} \mathrm{C}$ (Hadley and Pearson 1999). The notation by TheOPHRASTUS that coles are propagated by a piece torn off is interesting as vegetative propagation is indeed practised for cole crops with reduced flowering ability, such as perennial kale (Dias 2012). Vegetative propagation of $B$. oleracea was proposed to reproduce selected high yielding, stable self-incompatible or male-sterile lines (Frydrych 1975; Jahr 1980), before in vitro propagation became more efficient for this purpose (Torres et al. 1980). Transplanting at a sixleaf (Columella) or five-leaf (Pliny) stage corresponds to the current practice, since transplanting broccoli, cabbage, cauliflowers, etc. at a five or six leaf-stage is generally preferred to direct sowing in order to obtain a more uniform field and harvest.

Statements by VARro and Palladius about the occurrence of turnip plants from old seed of brassica could be an indication of the joint cultivation of these crops and the effects of easy intercrossing or mix-up of their seeds.

From the statements made by Columella, Pliny and PAlladius, we realize that harvesting times were dependent on the planting season, just as today. Winter products are mentioned by Columella to be caules (presumably cole heads or leafy kales), while spring products are the inflorescence shoots (cymata), as well as other shoots (cauliculos) collected in summer, fall and winter according to PLINY. These references recall the use of leafy kales that is still practised in home gardens in Italy, with inflorescence shoots harvested between January and May (e.g. 'Broccolo di
Paternopoli' or 'Broccolo di San Pasquale' in Campania) or tender vegetative shoots harvested between November and February (e.g. 'Broccolo Fiolaro di Creazzo' in Veneto).

Both Columella and Pliny discuss in particular the risk of going to flower too early (bolting). In their examples, the final desired product is called caule, which we have translated as 'cole', although we might perhaps read 'head', since, as of the I century C.E., we have reports of heading coles (PLINY's descriptions) and the word caule is no longer used to simply indicate the stem, but the entire crop.

The practices of weeding and manuring are reported by Columella and Pliny, indicating that these practices were customary by the I century C.E., if not before.

Regarding biotic and abiotic stresses, Columella mentions the problems of snails and bugs (conchae limax hirsutaque campe), heavy rains (duros imbres) and hail (grandine dilapidans). The much wider range of possible diseases that may affect today's cultivation is interestingly not much expanded in the ancient literature. Reference to the need of a long rotation before replanting coles on the same soil is made by PALladius, thereby indicating the occurrence of sick soil syndrome of brassica fields already in the IV century C.E.

\section{Conclusion and theories of Brassica oleracea domestication}

Several authors have attempted to draw hypotheses on the area where coles were initially domesticated and the genetic events that followed from there. The subject is complex, and the difficulty to reach any firm conclusion based on solid evidence is due to: (i) lack of archaeological remains (leafy and fleshy parts did not conserve well), (ii) lack of ancient illustrations, (iii) linguistic ambiguities that still persist until the present time (also due to the great polymorphism of the species), making it difficult to know for sure which morphologies correspond to which verbal expressions, (iv) the ability of this crop to easily intercross with a large number of wild relatives; (v) the high plasticity of the species, which easily escapes from cultivation and re-naturalizes in the wild; (vi) a history of travel, exchange and mixing of human populations in the Mediterranean and in Europe, who carried seed and 
food and possibly redistributed the crops wherever they travelled.

Brassica seeds are occasionally found in prehistoric archaeological excavations. However, reliable evidence of the use of $B$. oleracea in Neolithic or Bronze Age sites is currently missing, although records for $B$. rapa L. and B. nigra (L.) W.D.J. Koch are better documented (Schlichterle 1981; Körber-Grohne 1995). The difficulties in the identification of archaeo-botanical Brassica records are well described by Tomlinson and Hall (1996), who pointed out that there are no significant differences between different Brassica species in seed size and shape appropriate for the identification of Brassica fossil material. The online database of Dr Helmut Kroll on 'Literature on archaeological remains of cultivated plants 1981-2004' also indicates that no certain evidence could be found of $B$. oleracea archaeological remains before Roman times.

This crop was also apparently not sufficiently attractive to become a subject for decorative illustrations. Indeed, no records pertaining to $B$. oleracea have been found in a database of iconographic material of Roman sculptures and paintings dating from the first century B.C.E. and from the first three centuries C.E. from the geographical area of presentday Italy (Kumbaric and Caneva 2014).

From literary sources, as presented in this paper, it is possible to trace back proof of an already well consolidated tradition of knowledge and use of coles since at least the VI-V centuries B.C.E. in Greece. First descriptions of different cultivated varieties date back to the IV century B.C.E. with ThEOPHRASTus. He clearly indicated that both wild and domesticated types were used. The Greek medical tradition using the cole is testified indirectly by Latin authors, CATO and PLINY, referring to Pythagoras (VI century B.C.E.) and to Greek physicians of the IV-III centuries B.C.E. The use of coles as a simple food that is easily at hand in the kitchen or in the market, to be boiled in pots and used against drunkenness, is testified by several fragments of Greek literature. A similar presence is also apparent in the first literary Latin works of the IIIII centuries B.C.E. that have survived till today. The virtual absence of morphological descriptions offered by the Greeks and the earliest Latin scholars is eventually replaced in the I century C.E. by the description of at least 12 different types of cultivated forms, geographically distributed in central and south
Italy, with the majority in locations in Campania and Calabria, which is the land that hosted several Greek colonies.

Maggioni et al. (2010) already indicated linguistic and literary evidence pointing at a northeast Mediterranean location for the domestication of $B$. oleracea. They also indicated that the genetic data apparently supporting a northwest European site of domestication (Song et al. 1990) could rather be explained if all the populations of the Atlantic coast were escaped from the cultivation of crops imported from the Mediterranean (Grenier and Godron 1848; Mitchell 1976). This paper adds further weight to the hypothesis of Mediterranean domestication, by showing the size and number of references to B. oleracea that can be found in every corner of ancient Greek and Latin literature and nowhere else. The emerging picture is that of a crop that was extremely familiar in all spheres of life of these ancient civilizations. It is possible to delineate a sort of evolutionary pathway of the role of this crop. For the ancient Greeks it was a leafy vegetable to be boiled and dressed with olive oil. Only minimal diversity was known (either smooth or curly leaves) and the wild plant was still considered an option to bring on the table, even if more bitter or pungent. It was familiar enough as to be frequently mentioned in verbal expressions of comic exclamatory tone (By the krambē!). Great emphasis was given to its medicinal properties. Among these, the alleged antidotal effect against drunkenness was popular knowledge, while physicians compiled systematic handbooks to record properties and preparations against all sorts of diseases. From Latin literature we also derive the impression that coles were vegetables of widespread use, present in all vegetable gardens. They are often considered a simple food, associated with humble rural life. The high praise of this crop and of its medicinal properties seems to be not completely original in the case of CATO and PLiNY, who derive most of their knowledge on the subject from ancient Greek texts. However, around the I century C.E. Columella and Pliny describe an explosion of new forms and types, often associated with specific geographic locations. For the first time, the literary descriptions allow us to imagine that this crop was no longer just a leafy vegetable, but also that heading types had appeared. More or less at the same time it becomes apparent that a product of the crop in high demand is not just the leaves, but rather the tender 
inflorescence tops and sprouts (cymae or coliculi), growing from the leaf axils and re-shooting after being cut back. No clear reference to this use had been made earlier in the Roman or Greek world. The value of the sprouting inflorescences of either B. rapa or leafy kale B. oleracea is well known in present-day Italy (where they are still called cime or broccoletti). Interest in this part of the plant might have well exercised a selection pressure eventually leading to the development of broccoli and then cauliflowers.

The use of wild plants also seems to fade away with time, in the face of the abundance of new varied and productive types. These are described by PLINY not without a note of dismay for the modern monstrosities reaching the tables of his contemporaries (I century C.E.).

The overall picture emerging from this study stands out against the lack of equivalent historical records pertaining to $B$. oleracea from any other geographical area falling outside of the remit of the ancient Greek and Roman civilizations. It is therefore in this area, and for temporal reasons most likely the Aegean, that the domestication of B. oleracea can most logically have occurred.

Acknowledgements The authors wish to thank Arwen Bailey for her help in critical proofreading and English language editing.

\section{Compliance with ethical standards}

Conflict of interest The authors declare that they have no conflict of interest.

Open Access This article is distributed under the terms of the Creative Commons Attribution 4.0 International License (http:// creativecommons.org/licenses/by/4.0/), which permits unrestricted use, distribution, and reproduction in any medium, provided you give appropriate credit to the original author(s) and the source, provide a link to the Creative Commons license, and indicate if changes were made.

\section{References}

Note: all online sources were accessed on 14 March 2017

\section{Ancient (primary) sources}

This section lists the original works and provides references to the sources consulted (websites providing original texts and/or secondary sources listed in section 2)
ApICIUs (Marcus Gavius Apicius). De re coquinaria. [On the subject of cooking]. Online sources: (1) original: De re coquinaria/Liber III - Cepuros (http://la.wikisource.org/ wiki/De_re_coquinaria/Liber_III_-_Cepuros\#IX._Cimas_ et_coliclos); (2) translation: see Vehling JD 1936

ARETAEus. Oxeōn nousōn therapeutikon [On the therapeutics of acute diseases] and Kroniōn nousōn therapeuticon [On the cure of chronic diseases]. See Adams F 1972

Aristophanes. [Fragments]. See Henderson J 2008

Aristotle. Historia Animalium [The History of Animals]. See Peck AL 1952

Aristotle. Problemata [Problems]. See Hett WS 1961

Athenaeus. Deipnosophistēs [The Dipnosophists]. See Canfora L 2001

Aurelius Victor (Sextus Aurelius Victor). Epitome de Caesaribus. [A booklet about the style of life and the manners of the imperatores]. See Banchich TM 2009

Caesar (Julius Caesar). De Bello Civile [The Civil War]. See Lipparini G 1957

Cato (Marcus Porcius Cato Uticensis). De Agricultura [On Agriculture]. See Hooper WD 1934

Celsus (Aulus Cornelius Celsus). De Medicina [On Medicine]. See Spencer WG 1935

Cicero (Marcus Tullius Cicero). De Natura Deorum [On the Nature of the Gods]. See Brooks F 1896

Columella (Lucius Junius Moderatus Columella). De Re Rustica [On Agriculture]. See (a) Forster ES and Heffner EH 1954 and (b) Calzecchi Onesti R 1977

Diogenes LAertius. Biōn kai gnōmōn tōn en philosophiai eudokimēsantōn [Lives and Opinions of Eminent Philosophers]. See Hicks RD 1972

DiosCorides (Pedanius Dioscorides). De Materia Medica [On medical matters]. See Sprengel C 1829

Eudemus (Euthydemus of Athens). Peri lachanōn [On vegetables]. Cited by Athenaeus (Deip. 9.9)

Galen. De alimentorum facultatibus. [On the properties of foodstuffs]. See Powell O 2003

GALEN. De simplicium medicamentorum temperamentis ac facultatibus [On the mixtures and properties of simple drugs]. Quoted by The Online Liddell-Scott-Jones Greek-English Lexicon. http://stephanus.tlg.uci.edu/lsj/\#eid=1\& context=lsj

HiPPOCRATES. Gynaikeia (= De mulierum affectibus) [Diseases of Women]. The Online Liddell-Scott-Jones Greek-English Lexicon. http://stephanus.tlg.uci.edu/lsj/\#eid= $61481 \&$ context=lsj\&action=from-search

Hipponax. [Fragments]. Cited by Athenaeus (Deip. 9.9); see also Kugelmeier C 1996

Horace (Quintus Horatius Flaccus). Satirae [Satires]. See Smart, C and Buckley TA 1863

Juvenal (Decimus Iunius Iuvenalis). Satirae. [Satires]. See Barelli E 2004

Lucian of Samosata. Verae Historiae [A True Story]. See Harmon AM 1913

Martial (Marcus Valerius Martialis). Epigrammata. [Epigrams]. See Ker WCA 1919

Nicander. Geōrgika [Georgics]. Cited by Athenaeus (Deip. 9.9)

OvID (Publius Ovidius Naso). Metamorphoses [Metamorphoses]. See Paduano G 2007

Palladius (Palladius Rutilius Taurus Aemilianus). Opus agriculturae [Treatise on farming]. See Schmitt JC 1898 
Palladius of Galatia. Historia Lausiaca [The Lausiac History]. See Amélineau E 1894

Persius (Aulus Persius Flaccus). Satirae [Satires]. See Conington $\mathrm{J}$ and Nettleship H 1893

Plautus (Titus Maccius Plautus). Pseudolus. See Leo F 1895

Pliny the Elder (Gaius Plinius Secundus). Naturalis Historia [The Natural History]. See (a) Bostock J and Riley HT 1855 and (b) Aragosti A et al. 1985

Propertius (Sextus Propertius). Elegiae. [Elegies]. See Kline AS 2002, 2008

SERENUS (Quintus Serenus Sammonicus). Liber Medicinalis pr.1. [The Medical Book]. Online source: PHI Latin Texts. http://latin.packhum.org/loc/1515/1/0\#0

Theophrastus. Peri phyton historia [Enquiry into plants...]. See Hort A 1916

VArro (Marcus Terentius Varro). De Re Rustica [On Agriculture]. See Hooper WD and Ash HB 1934

VIRGIL (Publius Vergilius Maro). Moretum. See Mooney JJ 1916

\section{Secondary and contemporary sourcesdone}

Note: the secondary sources are listed under the names of the translator (tr)/editor (ed)

Adams F (ed and tr) (1972) The extant works of aretaeus, the cappadocian (Reprint of the 1856 edition). Milford House, Boston

Amélineau E (tr) (1894) Histoire des monastères de la BasseEgypte. Vies des Saints Paul, Antoine, Macaire, Maxime et Domèce Jean le Nain, \&a. Texte copte et traduction française par E. Amélineau. Annales du Musée Guimet, Tome vingt-cinquième. Ernest Leroux Editeur, Paris

André J (2009) L'alimentation et la cuisine à Rome. Klincksieck, Paris

Aragosti A, Centi R, Cosci P, Cotrozzi AM, Fantuzzi M, Lechi F (eds and trs) (1985) Gaio Plinio Secondo, Storia Naturale. III. Botanica. 2. Libri 20-27. Giulio Einaudi Editore, Torino

Banchich TM (tr) (2009) Epitome De Caesaribus. A booklet about the style of life and the manners of the imperatores. Sometimes Attributed to Sextus Aurelius Victor. Canisius College Translated Texts, Number 1, Canisius College. Buffalo, New York. 2nd edn. Online source: De Imperatoribus Romanis. An Online Encyclopedia of Roman Emperors. http://www.luc.edu/roman-emperors/epitome. htm

Barelli E (tr) (2004) Decimo Giunio Giovenale, Satire, 8th edn. BUR, Milano

Boivin D, Lamy S, Lord-Dufour S, Jackson J, Beaulieu E, Côte M, Moghrabi A, Barrette S, Gingras D, Béliveau R (2009) Antiproliferative and antioxidant activities of common vegetables: a comparative study. Food Chem 112:374-380

Boscherini S (1970) Lingua e scienza greca nel "De agri cultura" di Catone. Edizioni dell'Ateneo, Roma

Bostock J, Riley HT (trs) (1855) Pliny the Elder, Naturalis Historia [The natural history]. H. G. Bohn, London

Brooks F (tr) (1896) Marcus Tullius Cicero, De Natura Deorum [On the Nature of the Gods]. Online source: online library of liberty. http://oll.libertyfund.org/titles/539

Brullo C, Brullo S, Giusso Del Galdo G, Ilardi V (2013) Brassica trichocarpa (Brassicaceae), a new species from Sicily. Phytotaxa 122(1):45-60
Calzecchi Onesti R (tr) (1977) Columella, L'arte dell'Agricoltura. Einaudi, Torino

Canali L, Lelli E (2000) Catone il Censore, L'agricoltura. Mondadori, Milano

Canfora L (ed) (2001) Ateneo di Naucrati. I Deipnosofisti: I dotti a banchetto. Salerno editrice, Roma

Cerchiai Manodori Sagredo C (2004) Cibi e banchetti nell'antica Roma. Libreria dello Stato. Istituto Poligrafico e Zecca dello Stato, Roma

Conington J (tr and comm), Nettleship N (ed) (1893) The satires of A. Persius Flaccus, 3rd edn, revised. Clarendon Press, Oxford. Online source. http://www.archive.org/stream/ satiresofapersiu00persuoft

De Saint-Denis E (1980) Éloge du chou. Latomus 39:838-849

Dias JS (2012) Portuguese perennial kale: a relic leafy vegetable crop. Genet Resour Crop Evol 59:1201-1206

Drenckhahn D (2017) Vorkommen des Atlantischen Wildkohls (Brassica oleracea L. subsp. oleracea) and den Kreidefelsen der Ostseeinsel Rügen, Deutschland. Forum geobotanicum 7:18-26

Ernout A, Meillet A (1932) Dictionnaire étymologique de la langue latine. Histoire des mots. Ed. Klincksieck, Paris

Estienne H (1831-1865) Thesaurus Graecae Linguae ab Henrico Stephano constructus, 8 tomes, 9 volumes. In: Hase B, Dindorf W, Dindorf L et al (eds). Firmin Didot, Paris

Facciolati J, Forcellini A, Furlanetti J (eds) (1864-1887) Lexicon Totius Latinitatis, 4 volumes. Typis Seminarii, Patavii [Padua]

Forster ES (1936) Trees and plants in Homer. Classical Rev 362(50):97-104

Forster ES, Heffner EH (trs) (1954) Columella. On agriculture, volume II: books 5-9. Loeb Classical Library 407. Harvard University Press, Cambridge

Frydrych J (1975) A contribution to the vegetative propagation of Brassica crops. I. Kohl rabi and cabbage [in Czech]. Bulletin, Vyzkumny Ustav Zelinarsky 19(20):137-145

Gladis T, Hammer K (2003) Die Brassica-oleracea-Gruppe. Schriften des Vereins zur Erhaltung der Nutzpflanzenvielfalt No.1. VEN, Lennestadt

Grenier M, Godron M (1848) Flore de France. J. B. Baillière, Paris

Guerrero-Beltrán CE, Calderón-Oliver M, Pedraza-Chaverri J, Chirino YI (2012) Protective effect of sulforaphane against oxidative stress: recent advances. Exp Toxicol Pathol 64:503-508

Hadley P, Pearson S (1999) Physiology. In: Gómez-Campo C (ed) Biology of Brassica coenospecies. Elsevier, Amerstadam, pp 359-373

Harmon AM (tr) (1913) Lucian, vol I. Loeb Classical Library 14. Harvard University Press, Cambridge

Haynes C, Everhart E, Jauron R, Nelson D, Lenahan J (2009) Cole Crops. Iowa State University, University Extension. http:// www.extension.iastate.edu/Publications/PM1896.pdf

Helm J (1960) Brokkoli und Spargelkohl. Beiträge zur Geschichte ihrer Kultur und zur Klärung ihrer morphologischen und taxonomischen Beziehungen untereinander sowie zum Blumenkohl. Züchter 30:223-241

Helm J (1963) Morphologisch-taxonomische Gliederung der Kultursippen von Brassica oleracea L. Kulturpflanze 11:92-210 
Henderson J (ed and tr) (2008) Aristophanes V. Fragments. Loeb Classical Library 502. Harvard University Press

Hervé Y (2003) Choux. In: Pitrat M, Foury C (eds) Histoires de légumes: des origines à l'orée du XXIè siècle. INRA, Paris, pp 222-234

Hett WS (tr) (1961) Aristotle. Problems, vol 1. William Heinemann, London

Hicks RD (tr) (1972) [reprint]. Diogenes Laertius. Lives of eminent philosophers. Loeb Classical Library 184-185. Harvard University Press, Cambridge (First published 1925)

Hodgkin T (1995) Cabbages, kales, etc. Brassica oleracea (Cruciferae). In: Smartt J, Simmonds JW (eds) Evolution of crop plants, 2nd edn. Longman Scientific \& Technical, Harlow, pp 76-82

Hondelmann W (2002) Die Kulturpflanzen der griechischrömischen Welt: pflanzliche Ressourcen der Antike. Bornträger, Berlin-Stuttgart

Hooper WD, Ash HB (trs) (1934) Cato and Varro. On agriculture. Loeb Classical Library 283. Harvard University Press, Cambridge

Hort AF (tr) (1916) Theophrastus. Enquiry into plants and minor works on odours and weather signs, vol 1, books 1-5. Loeb Classical Library 70. Harvard University Press, Cambridge

Jahr W (1980) Problematik der Linierhaltung bei Blumenkohl. Tagungsbericht, Akademie der Landwirtschaftswissenschaften der Deutschen Demokratischen Republik 168:431-438

Janick J, Hummer KE (2012) The 1500th anniversary (5122012) of the Juliana Anicia Codex: an illustrated dioscoridean recension. Chron Hortic 52(3):9-15

Joseph MA, Moysich KB, Freudenheim JL, Shields PG, Bowman ED, Xhang Y, Marshall JR, Ambrosone CB (2004) Cruciferous vegetables, genetic polymorphisms in glutathione s-transferases $\mathrm{m} 1$ and $\mathrm{t} 1$, and prostate cancer risk. Nutr Cancer 50:206-213

Ker WCA (tr) (1919) Martial. Epigrams. William Heinemann, G.P. Putnam's Sons, London, New York

Kline AS (tr) (2002, 2008) Propertius: the elegies. Book IV.2:1-64 The God Vertumnus. Online source. http:// www.poetryintranslation.com/PITBR/Latin/PropertiusBk Four.htm\#anchor_Toc201112556

Körber-Grohne U (1995) Nutzpflanzen in Deutschland von der Vorgeschichte bis heute. Konrad Theiss, Stuttgart

Kugelmeier C (1996) Reflexe früher und zeitgenössischer Lyrik in der alten attischen Komödie. Teubner, Stuttgart

Kumbaric A, Caneva G (2014) Updated outline of floristic richness in Roman iconography. Rendiconti Lincei 25:181-193

Lauffer S (ed) (1971) Bibliotheca Augustana: Edictum de pretiis rerum venalium. Textus: Diokletians Preisedikt. Siegfried Lauffer, Berlin. http://www.hs-augsburg.de/ harsch/ Chronologia/Lspost04/Diocletianus/dio_ep_i.html

Leo F (ed) (1895) T. Maccius Plautus. Plauti Comoediae. Weidmann, Berlin

Library of Congress (2010) ALA-LC romanization tables: Greek. http://www.loc.gov/catdir/cpso/roman.html

Liddell HG, Scott R (1982) A Greek-English lexicon, 8th edn. Clarendon Press, Oxford. Online version available from the Thesaurus Linguae Graecae ${ }^{\circledR}$ at http://stephanus.tlg.uci. edu/lsj/\#eid=1\&context=lsj
Lin HJ, Probts-Hensch NM, Louie AD, Kau IH, Witte JS, Ingles SA, Frankl HD, Lee ER, Haile RW (1998) Glutathione transferase null genotype, broccoli, and lower prevalence of colorectal adenomas. Cancer Epidemiol Biomarkers Prev 7:647-652

Lipparini G (tr) (1957) Caio Giulio Cesare. La Guerra Civile (Latin text and Italian translation). Zanichelli, Bologna

Madhu AK, Javed M (2016) Impact of supplementation of broccoli powder (Brassica oleracea $\mathrm{L}$. var. italica Plenck) on blood glucose and lipid profile of non-insulin dependent diabetics. IJBAAR 14(1):94-103

Mageney V, Neugart S, Albach DC (2017) A guide to the variability of flavonoids in Brassica oleracea. Molecules 22:252. doi: $10.3390 /$ molecules 22020252

Maggioni L, von Bothmer R, Poulsen G, Branca F (2010) Origin and domestication of cole crops (Brassica oleracea L.): linguistic and literary considerations. Econ Bot 64(2):109-123

Matthioli PA (1568) [Facsimile edition 1968] I Discorsi di M. Pietro Andrea Matthioli sanese, medico cesareo et del serenissimo principe Ferdinando archiduca d'Austria \& c. nelli sei libri di Pedacio Dioscoride Anazarbeo della materia medicinale (...). Secondo Libro. Edizione curata da Roberto Peliti. Riproduzione in fac-simile dell'edizione Veneziana del 1568 di Vincenzo Valgrisi. Stabilimento Tipografico Julia, Roma, 1968

Medina S, Domínguez-Perles R, Moreno DA, García-Vigueira C, Ferreres F, Ignacio Gil I, Gil-Izquierdo Á (2015) The intake of broccoli sprouts modulates the inflammatory and vascular prostanoids but not the oxidative stress-related isoprostanes in healthy humans. Food Chem 173:1187-1194

Milnor K (2014) Graffiti and the literary landscape in Roman Pompeii. Oxford University Press, Oxford

Mitchell ND (1976) The status of Brassica oleracea L. subsp. oleracea (Wild Cabbage) in the British Isles. Watsonia 11:97-103

Mooney JJ (tr) (1916) The Minor Poems of Vergil: comprising the Culex, Dirae, Lydia, Moretum, Copa, Priapeia, and Catalepton. Cornish Brothers, Birmingham

Mori E (2015) Carmina priapea. Testo latino con traduzione in lingua italiana. Online source: http://www.mori.bz.it/ humorpage/carmina.pdf

Novosadyuk YN (1988) The effects of various agricultural crop plants on grapevine [in Russian]. Biologiya Vinograda $\mathrm{i}$ Razrabotka Ėlementov Progessivnoř Tekhnologii Ego Razmnozheniya i Vozdelyvaniya, pp 33-38

Paduano G (tr) (2007) Ovidio. Le Metamorfosi. Mondadori, Milano

Peck AL (tr) (1952) Aristotle: Historia Animalium, vol II. William Heinemann Ltd, London

Podsędek A, Sosnowska D, Redzynia M, Anders B (2006) Antioxidant capacity and content of Brassica oleracea dietary antioxidants. Int $\mathrm{J}$ Food Sci Tech 41(Suppl 1):49-58

Powell O (tr and comm) (2003) Galen. On the properties of foodstuffs (De alimentorum facultatibus). Cambrige University Press

Prakash S, Wu XM, Bhat SR (2011) History, evolution, and domestication of Brassica crops. In: Janick J (ed) Plant Breed Rev 35:19-84. Wiley, Hoboken 
Reymond EAE (ed) (1976) A medical book from Crocodilopolis: P. Vindob. D. 6257. From the contents of the libraries from the Suchos Temples in the Fayyum. Part I. Brüder Hollinek, Vienna

Schlichterle H (1981) Cruciferen als Nutzpflanzen in neolitischen Ufersiedlungen Südwestdeutschlands und der Schweiz. ZArchaol 15:113-124

Schmitt JC (1898) Palladius Rutilius Taurus Aemilianus (4th cent.) Opus agriculturae. Teubner, Leipzig

Sedgwick WB (1930) The Dating of Plautus' plays. Class Q 24(2):102-106

Smart C (tr), Buckley TA (annot) (1863) The works of Horace. Harper \& Brothers, New York

Snogerup S (1980) The wild forms of the Brassica oleracea group $(2 \mathrm{n}=18)$ and their possible relations to the cultivated ones. In: Tsunoda S, Hinata K, Gómez-Campo C (eds) Brassica crops and wild allies. Biology and breeding. Japan Scientific Societies Press, Tokyo, pp 121-132

Snogerup S, Gustafsson M, von Bothmer R (1990) Brassica sect. Brassica (Brassicaceae): I. Taxonomy and variation. Willdenowia 19:271-365

Soengas P, Sotelo T, Velasco P, Cartea ME (2011) Antioxidant properties of Brassica vegetables. Func Plant Sci Biotech 5(2):43-55

Song K, Osborn TC, Williams PH (1990) Brassica taxonomy based on nuclear restriction fragment length polymorphisms (RFLPs). 3. Genome relationship in Brassica and related genera and the origin of $B$. oleracea and $B$. rapa (syn. campestris). Theor Appl Genet 79:497-506

Spencer WG (tr) (1935) Celsus. On medicine, vol I. Books 1-4. Loeb Classical Library 292. Harvard University Press

Spitz MR, Duphorne CM, Detry MA, Pillow PC, Amos CI, Lei L, de Andrade M, Gu XJ, Hong WK, Wu XF (2000) Dietary intake of isothiocynataes: evidence of a joint effect with glutathione S-transferase polymorphisms in lung cancer risk. Cancer Epidemiol Biomarkers Prev 9:1017-1020

Sprengel C (ed and tr) (1829) Pedanii Dioscoridis Anazarbei: De Materia Medica: Libri Quinque (...). Tomus Primus. In: Kühn CG (ed) Medicorum Graecorum Opera Quae Exstant (...). Volumen XXV Continens Pedanium Dioscoridem Anazarbeum. [C. Cnobloch], Lipsiae [Leipzig]

Thesaurus Linguae Latinae (1906-1912) Editus auctoritate et consilio academiarum quinque Germanicarum Berolinensis, Gottingensis, Lipsiensis, Monacensis, Vindobonensis. Teubner, Leipzig

Thesaurus Linguae Graecae ${ }^{\circledR}$ Digital Library (2014) Ed. Maria C. Pantelia. University of California, Irvine. http://www. tlg.uci.edu

Thompson KF (1976) Cabbages, kales, etc. Brassica oleracea (Cruciferae). In: Simmonds NW (ed) Evolution of crop plants. Longman, London, pp 49-52

Tomlinson P, Hall AR (1996) A review of the archaeological evidence for food plants from the British Isles: an example of the use of the Archaeobotanical Computer Database (ABCD), Internet Archaeology, (1). Council for British Archaeology. doi:10.11141/ia.1.5. http://intarch.ac.uk/ journal/issue1/tomlinson_index.html
Torres AC, Vecchia PTD, Souza ELS, Caldas LC (1980) Vegetative propagation of sprouting broccoli (Brassica oleracea L. var. italica) by means of tissue culture, with the aim of maintaining self-sterile lines. Rev Ceres 27(149):83-90 (in Portuguese)

Toscano S, Scuderi D, Tribulato A, Romano D (2013) Ethnobotanical uses of Brassicaceae by the ancient Romans. Proceedings of the VI International Symposium on Brassicas and XVIII Crucifer Genetics Workshop (Branca F, Tribulato A, eds). Acta Hor 1005:205-212

Toxopeus H (1974) Outline of the evolution of turnips and coles in Europe and the origin of winter rape, swede-turnips and rape kales. In: Wills $\mathrm{AB}$, North $\mathrm{C}$ (eds) Proceedings of Eucarpia meeting "Cruciferae 1974", Dundee, 25-27 September 1974. Scottish Horticultural Research Institute, Invergrownie, pp 1-7

Traka M, Mithen R (2009) Glucosinolates, isothiocyanates and human health. Phytochem Rev 8:269-282

Ushida Y, Suganuma H, Yanaka A (2015) Low-dose of the sulforaphane precursor glucoraphanin as a dietary supplement induces chemoprotective enzymes in humans. Food Nutr Sci 6(17):1603-1612

Vehling JD (tr) (1936) Cooking and dining in imperial rome, by Apicius. W. M. Hill, Chicago. Online source: Bill Thayer's website. http://penelope.uchicago.edu/Thayer/E/Roman/ Texts/Apicius/3*.html

Verkerk R, Tebbenhoff S, Dekker M (2010) variation and distribution of glucosinolates in 42 cultivars of Brassica oleracea vegetable crops. Acta Hort 856:63-69

WebMD (2017). http://www.webmd.com/

Yamagishi SI, Matui T (2016) Protective role of sulforaphane against vascular complications in diabetes. Pharm Biol 54(10):2329-2339

Zohary D, Hopf M, Weiss E (2012) Domestication of plants in the Old World, 4th edn. Oxford University Press, Oxford

\section{Online sources providing original texts or translations}

Bill Thayer's website. http://penelope.uchicago.edu/Thayer/E/ home.html

Corpus Scriptorum Latinorum. www.forumromanum.org/ literature

The Hibeh papyri. http://www.archive.org/stream/hibehpapy ri01egypuoft/hibehpapyri01egypuoft_djvu.txt

The Latin Library. www.thelatinlibrary.com

The online database of Dr Helmut Kroll on 'Literature on archaeological remains of cultivated plants 1981-2004'. http://www.archaeobotany.de

Papyri info. http://papyri.info/

The Perseus Digital Library. www.perseus.tufts.edu

POxy: Oxyrhynchus Online. A guide and online database for the Oxyrhynchus Papyri. http://www.papyrology.ox.ac.uk/ POxy/

The Theoi Classical E-Texts Library. www.library.theoi.com Wikipedia. www.wikipedia.org 